\section{Politics and Literature}

The Best Paper Award is given for the best paper on politics and literature delivered at the previous APSA Annual Meeting. The 1999 prize went to Paul Cantor of the University of Virginia for "The Simpsons: Atomistic Politics and the Nuclear Family."

\section{Domestic Sources of Foreign Policy}

The Best Paper Award was won by Richard Sinnott from University College, Dublin for his work,

"Knowledge and the Position of Attitudes to a European Foreign and Security Policy on the Real-toRandom Continuum." The award is presented for the best paper on domestic sources of foreign policy presented at the previous APSA Annual Meeting.

\section{Elections, Public Opinion and Voting Behavior}

Stan Humphries of the University of Virginia took home the 1999 Best Paper Award for "The Impact of Economic Structure on Social Capital and Civic Engagement." The
Philip E. Converse Book Award for an outstanding book in the field published at least five years before went to Anthony Downs of The Brookings Institution for his book, An Economic Theory of Democracy (Harper and Row, 1957). The Emerging Scholar Award, for the top scholar in the field who is within 10 years of her or his Ph.D., went to Wendy Rahn of the University of Minnesota.

\section{Race, Ethnicity and Politics}

The Organized Section on Race, Ethnicity and Politics presented a number of awards, including three book prizes. The Best Book Award on the Social Construction of Race went to Matthew Frye Jacobson of Yale University for Whiteness of $a$ Different Color: European Immigrants and the Alchemy of Race (Harvard University Press, 1998). The Best Book Award on Racial Identity went to Andra Y. Simpson, University of Washington, for her book, The Tie that Binds: Identity and Political Attitudes in the Post-Civil Rights Generation (New York University Press, 1998). The Best Book Award on Intersections of Race and Gender

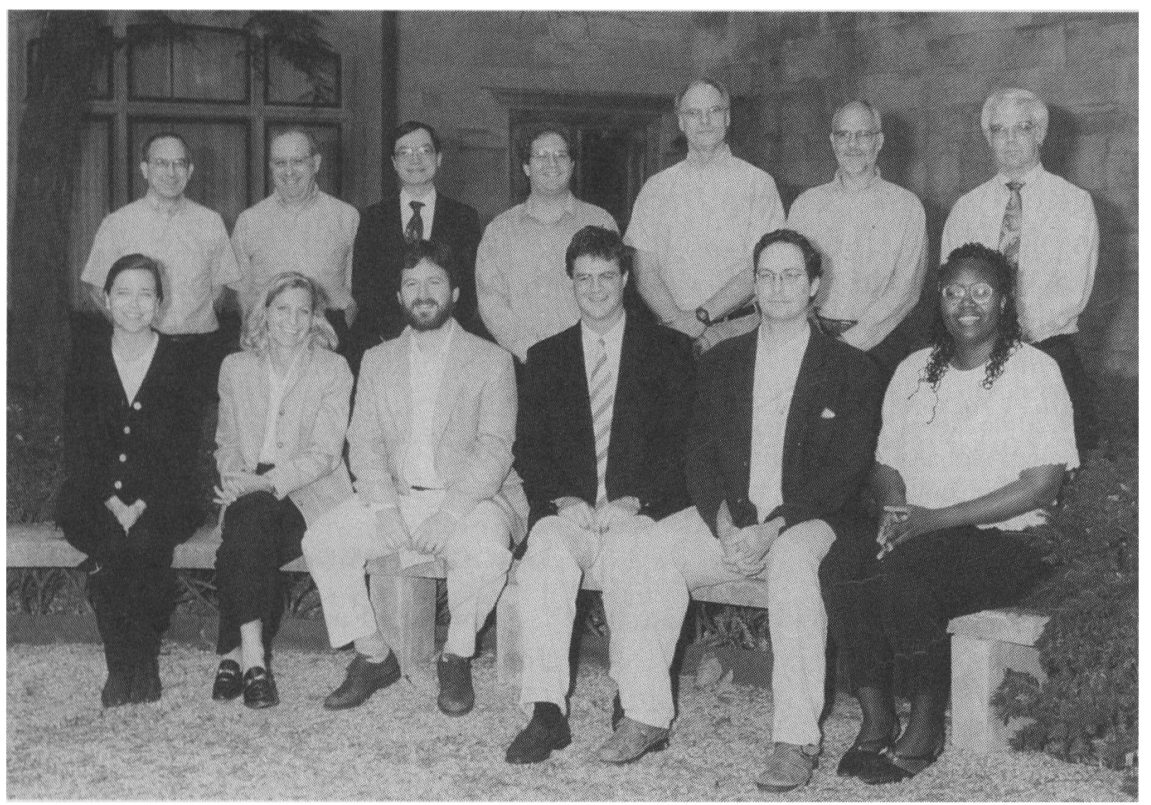

Scholars at NSF-Funded Conference at IU. $(R-L)$ Top Row: Richard Niemi, University of Rochester; Michael Cohen, Indiana University-Purdue University at Indianapolis; Kenneth Wong, University of Chicago; David Figlio, University of Florida; Kenneth Meier, Texas A \& M University; Mark Schneider, SUNY-Stony Brook; and Thomas Huberty, Indiana University. Boltom Row: Elizabeth Smith, Furman University; Melissa Marschall, University of South Carolina; Bradley Levinson, Indiana University; Michael Shanahan, Pennsylvania State University; Robert Smith, Barnard College; and Yvette Alex-Assensoh, Indiana University.

was awarded to Luana Ross of the University of California, Davis for Inventing the Savage: The Social Construction of Native American Criminality (University of Texas Press, 1998). The Best Book Award on Ethnic Political Incorporation was presented to Michael Jones-Correa of Harvard University for Between Two Nations: The Political Predicament of Latinos in New York City (Cornell University Press, 1998).

\section{Scholars Attend IU Conference}

Drawn together by their common research interests in children and adolescent issues, 13 scholars from various U.S. universities, colleges, and academic institutions came together at Indiana University this August for "Multidisciplinary Pathways to Children's Learning, Development and Transitions to Adulthood." Dr. Yvette Alex-Assensoh, an assistant professor of political science at Indiana and a former Ralph Bunche Summer Institute scholar, organized the three-day conference.

Funded by the National Science Foundation (NSF), the conference attracted political scientists, economists, cultural anthropologists, sociologists, and a nursing instructor.

Participants presented papers on and discussed the plethora of factors that promote and impede educational attainment and development among American youth. Specifically, participants addressed transitions to adulthood, school-related processes and education, and politics and competing models of educational reform. A highlight of the conference was a town meeting at which members of the local school board, principals, teachers, former university students and local government officials discussed the increased severity of and apparent increase in the frequency of violence at school.

\section{OMB Finalizes Rules on Data Sharing}

True to the timetable it set for itself, the Office of Management and 